\title{
Bruno, não Franz: a primeira onda da recepção de Ficção Completa do polonês Bruno Schulz ${ }^{1}$
}

\author{
Gabriel Borowski
}

\begin{abstract}
Resumo: Opresente artigo propõe uma análise detalhada dos primeiros momentos da recep̧ãa de Ficção Completa (Cosac Naify, 2012), do escritor polonês Bruno Schulz. (1892-1942), que constitui a primeira edição da totalidade da obra ficcional do autor em lingua portuguesa. Por meio de um estudo das circunstâncias da sua publicação e das primeiras repercussões críticas, este trabalho visa lançar uma luz sobre o processo da construção da imagem do autor traduzido na cultura de chegada, com uma ênfase particular na função dos contextos preexistentes enquanto componentes de um quadro receptivo mais complexo. O ensaio sublinha também a importância do tradutor enquanto expert e orientador, ou seja, um agente ativo no processo de recep̧cão.
\end{abstract}

Palavras-chave: Bruno Schulz, tradução literária, recepção, literatura polonesa.

Seu parentesco com Kafke a tanto pode abrir como fechar-lhe o caminho. Se disserem que é mais um primo, está perdido. Witold Gombrowicz (apud SCHULZ, 2012, p. 391)

"A viagem para o mundo" (STALA, 1995, p. 24) ou "a carreira póstuma de Schulz no exterior" (JARZĘBSKI, 1998, p. CXXVI), iniciadas no final da década de 50, constituem, sem dúvida, um dos campos mais diversificados e ricos para a pesquisa sobre a recepção da literatura polonesa em realidades linguístico-culturais muito diferentes. Traduzida para pelo menos quarenta idiomas ${ }^{2}$, a obra literária

1 Texto originalmente publicado em língua polonesa na revista "Przekładaniec: A Journal of Translation Studies” (27/2013), publicada pela Universidade Jaguelônica em Cracóvia (Polônia).

2 Cf. a página eletrônica: http://www.brunoschulz.org/wydania.htm. Consulta realizada a 20 de dezembro de 2015 . 
de Bruno Schulz foi repetidamente sujeita a um processo de inserção em vários sistemas literários, o que sempre implicava em uma negociação de sua posição dentro do espaço da cultura-alvo ( $f$. EVEN-ZOHAR, 1990). A criação inovadora do autor polonês pode constituir uma componente ativa no sistema de chegada enquanto um ponto de partida para a ampliação do repertório de formas e temas disponíveis. Como observa Krzysztof Stala:

Em muitos países Schulz é considerado um escritor totalmente "contemporâneo", ainda estimulante e intrigante. Na Espanha costuma ser enumerado junto com Kafka e Musil como um dos inspiradores da renovação da ficção espanhola nos anos oitenta; na Suécia, os melhores escritores falam do seu deslumbre com traduções relativamente $(1983,1987)$ recentes; John Updike analisa a sua obra comparando-a com Borges, Proust, Kafka, Danilo Kiš. O recluso de Drohobych está se tornando gradativamente um "cidadão do mundo". (STALA, 1995, p. 24)

Schulz consegue a sua "cidadania mundial" através da inserção em novas realidades culturais, realizada no processo de recepção, que leva, entre outros, à identificação de contextos e analogias que permitam situar o texto em um continuum histórico-literário e crítico da cultura-alvo. Sustentam-se, desse modo, as palavras de Aleksander Fiut:

A escrita do autor de As lojas de canela, antes de ganhar o direito a uma cidadania própria e de ser considerada e reconhecida no seu caráter inigualavelmente distinto, original e singular, chegará à opinião internacional por meio de outras leituras mais conhecidas ou assimiladas há muito mais tempo. (FIUT 2003, p. 497)

Como se realiza esta "entrada no imaginário" (FIUT, 2003 p. 498)? Qual é a dinâmica da assimilação da ficção idiomática do escritor polonês? Será que as manifestações desse processo podem ser apontadas e descritas? Desde as primeiras traduções de Schulz, evocadas por Stala (1995, p. 24) - para o espanhol (1962) ${ }^{3}$, inglês (1958) e sueco (1962), entre outras - já passou mais de um meio século. O

3 É interessante observar, aliás, que as primeiras traduções de Schulz para a língua espanhola foram publicadas na América Latina. Segundo os dados no site http://www.brunoschulz.org, as primeiras traduções de textos esparsos foram editadas na Venezuela (1962), na Colômbia (1962), na Argentina (1965) e no México (1967). Em 1972, foi publicado, na Argentina, o volume La calle de los cocodrilos (traduzido por E. Gohre) e, em Barcelona, Las tiendas de color canela (traduzido por S. Puig). 
prefácio de John Updike, de 1978, bem como o "deslumbramento" dos suecos e espanhóis, são fatos ocorridos há cerca de trinta anos. Será que Bruno Schulz ainda consegue estimular e intrigar o leitor estrangeiro? Quais são as deformações contextuais do seu perfil e da sua obra em realidades que possuem um arquivo histórico e literário diferente? No caso dos sistemas literários em que a ficção de Schulz está presente há décadas (como acontece com os leitores das traduções inglesas, suecas, espanholas, francesas etc.), os assuntos mencionados levam (já) a uma indagação sobre a história da recepção do autor de As lojas de canela, ou seja, equivalem a um convite a pesquisas bibliográficas (aliás, muito interessantes também). Nesse caso, a distância temporal que separa o pesquisador do seu objeto permite a constituição de uma perspectiva em que as pistas são enxergadas de uma maneira regressiva em relação às suas posteriores consequências.

Este ensaio, porém, dedicado aos primeiros momentos da recepção da primeira edição completa da ficção de Bruno Schulz (2012a) no Brasil ${ }^{4}$, é privado dessa distância temporal e visa à observação dos mecanismos da recepção "no calor do momento". Através de uma análise das circunstâncias da publicação e das primeiras reações da crítica, procura lançar uma luz sobre algumas particularidades do processo de construção da imagem do autor traduzido, na realidade receptora, com ênfase especial nos modos de sua contextualização por meio das referências preexistentes que funcionam como um quadro de recepção.

A presente análise se baseia em um modelo heurístico derivado das observações de André Lefevere (1982, p. 5), segundo o qual "[literature] is a contrived

4 Ainda que o presente artigo se concentre na realidade cultural do Brasil, convém observar que Bruno Schulz está presente também em Portugal desde a década de 70, quando saiu a antologia Contos polacos (1977) com uma tradução - indireta, através do espanhol - feita por José Saramago. Em 1983 foi publicado Tratato dos manequins, e em 1987 - o volume completo As lojas de canela na tradução de Aníbal Fernandes que, infelizmente, deixa muito a desejar. A versão de Fernandes, elaborada a partir da tradução inglesa e francesa, castra a ficção de Schulz no que diz respeito às suas particularidades formais. Na reedição de 2012 (SCHULZ, 2012b), é incluído um prefácio muito mal preparado, no qual, para além de lapsos oriundos da ignorância da redação (a ortografia inglesa - "Arthur" - do nome do famoso crítico polonês Artur Sandauer, ou a moeda "zloti" - a grafia segue a pronúncia inglesa - em vez de "złoty"), faltam explicações e comentários referentes à realidade polonesa (por exemplo, o que significa a abreviação "zl" - que vem do nome da moeda oficial e deve ser escrita "zł" - ou a importância da rua Floriańska, na Cracóvia - uma das ruas principais na parte mais antiga da cidade) e à sua vida artística (Witkiewicz, um dos nomes principais na cultura polonesa da época e de todo o século XX, é apresentado apenas como "outro artista plástico-escritor ou vice-versa" [SCHULZ, 2012b, p. 9] ). As informações históricas superam o substrato biográfico - embora Fernandes cite uma carta aberta em que Schulz chama atenção ao caráter autobiográfico da sua obra - e o escritor parece retratado como uma mera vítima das turbulências históricas. A editora portuguesa aparentemente não usufruiu as experiências da primeira onda da recepção da tradução brasileira, o que poderia ter permitido evitar uma série de equívocos. 
system, i.e. it consists of both objects (texts) and people who write, refract, distribute, read those texts." É decisiva, portanto, uma análise da atividade das instâncias que desempenham um papel regulador dentro do sistema (isto é, exercem "patronagem") e são responsáveis pela "refração", ou seja, a deformação resultante de uma negociação entre o sistema de partida e o sistema de chegada, contemplando as suas limitações ( $c f$. LEFEVERE, 1982). O objetivo deste ensaio consiste, portanto, na apresentação das ações dos agentes de patronagem (comentários públicos de críticos literários, ensaístas, professores, acadêmicos etc.) e na exposição do papel do tradutor enquanto um sujeito que exerce uma influência ativa sobre o processo da recepção ( $f f$. MILTON, BANDIA, 2009) e da criação do cânone da literatura traduzida no exterior (cf. WILCZEK, 2011).

\section{Tradutor como orientador}

Em 21 de dezembro de 2012, o suplemento "Caderno 2" de "O Estado de S. Paulo" publica uma síntese do ano, acompanhada por um resumo dos acontecimentos mais importantes em dez categorias. No campo da literatura, Fiç̧ão Completa de Bruno Schulz, editada havia seis meses, ocupa o primeiro lugar, superando, entre outros, as novas traduções de Ulisses, de James Joyce, e de $O$ arco e a lira, de Octavio Paz, as novas edições de A comédia humana, de Balzac, e de Laranja mecânica, de Burgess, e as primeiras traduções brasileiras de Contra o dia, de Thomas Pynchona, O sentido de um fim, de Julian Barnes e Um olhar sobre Giacometti, de David Sylvester (BRASIL, 2012, p. D6) ${ }^{5}$. Há apenas dois livros de autores nacionais neste destaque: uma estréia (José Luiz Passos) e uma reedição (Pedro Nava) ${ }^{6}$.

5 A ordem desta enumeração não corresponde à ordem apresentada no jornal, que é a seguinte: 1 . B. Schulz, 2. J. Joyce, 3. H. Balzac, 4. T. Pynchon, 5. D. Sylvester, 6. J.L. Passos, 7. P. Nava, 8. O. Paz, 9. A. Burgess, 10. J. Barnes.

6 Se considerarmos este ranking enquanto representativo para a tendência geral presente no sistema literário brasileiro, ele pode servir de base para uma hipótese pertinente do ponto de vista da análise da recepção da obra de Bruno Schulz no Brasil. A desproporção entre a literatura nacional e a as traduções, bem como o caráter inovador, muitas vezes experimental das obras traduzidas (Joyce, Paz, Burgess, Pynchon) indicam que a literatura traduzida não se situa na periferia do sistema literário local, mas antes constitui nele um elemento importante, responsável pela ampliação do repertório de formas e temas disponíveis. No sistema literário no Brasil - um sistema relativamente ainda "novo", "periférico", "fraco" ( $c f$. EVEN-ZOHAR, 1990) - a literatura traduzida introduz (estréias) ou atualiza (reedições) forças transformadoras, inclusive novos códigos e padrões composicionais, que, como sugere a retrospectiva de 2012, são muito apreciados pelo público e pelos críticos desejosos de novidades. A ficção de Schulz, que "enxergado de um certo ponto de vista (...) fica (...) no topo dos inovadores da ficção polonesa (e mundial) da primeira metade do nosso século [XX]" (JARZĘBSKI, 1998, p. cvi), harmonizaria com esta tendência. Caso não 
Em uma nota muito sucinta sobre Fição Completa lê-se que "ancorado pelas culturas polonesa, judaica e alemã, Bruno Schulz (...) escreveu uma obra curta, mas intensa, traduzida por Henryk Siewierski e editada pela Cosac Naify" (BRASIL, 2012, p. D6). Vale lembrar que a editora paulista, fundada em 1997, é responsável pelo lançamento de obras-primas da literatura mundial, como escritos de Victor Hugo, Lev Tolstói ou Herman Melville?. Um destaque especial no seu catálogo é a coleção "Prosa do Mundo", iniciada em 2000, apresentada pela editora da seguinte maneira:

A Prosa do Mundo reúne clássicos e obras de grande importância da literatura estrangeira ainda desconhecidas no Brasil. Em tradução direta do original, com preciosos textos complementares de autores como Roland Barthes, Henry James, Julio Cortázar e Tarsila do Amaral, os livros formam uma biblioteca essencial para leitores ávidos por literatura e cultura e apreciadores de belas edições. ${ }^{8}$

Na prestigiosa coleção foram lançadas obras de Tolstói, Pirandello, Beckett, Brecht, Mauriac, Tchekhov, Melville, Bataille, Stendhal, Flaubert, Jünger, Canetti, Breton e Stevenson, entre outros. Fiç̧ão Completa, editada em 2012, inaugura um novo decênio da existência da série. A inclusão da obra de Schulz na "Prosa do Mundo" constitui um quadro de referência para os possíveis leitores, comunicando que o autor pertence a um grupo de elite, composto por clássicos da literatura mundial. As circunstâncias da publicação sugerem também que o público-alvo da tradução constitui leitores exigentes, "eruditos", apreciadores de clássicos, e ao mesmo tempo abertos a padrões composicionais e linguagens poéticas oriundos do exterior. O preço do volume também não deixa de ser significativo: R \$ 89,00 que parece ser um valor acessível somente pelas camadas mais altas da sociedade brasileira. ${ }^{9}$

haja outra indicação, as traduções das fontes citadas da língua polonesa para o português são da responsabilidade do autor deste ensaio.

7 Veja o site oficial da editora: https://editora.cosacnaify.com.br. Consulta realizada em 20 de dezembro de 2015.

8 https://editora.cosacnaify.com.br/SubHomeSecao/566/Prosa-do-Mundo.aspx. Consulta realizada em 20 de dezembro de 2015.

9 Autor de uma das resenhas que serão mencionadas mais adiante considera o preço do volume "O único defeito [...] que, embora possa ser economicamente justificável, é digno de lamento como empecilho à circulação da obra de um gênio. Schulz é bom demais para se restringir às estantes da elite" (RODRIGUES, 2012). Vale observar, porém, que a Cosac Naify regularmente oferece descontos a 30-40\%. (Desde 
A edição em questão, com mais de 400 páginas, incorpora traduções de Lojas de canela, Sanatório sob o signo da clepsidra e quatro contos esparsos ("Outono", "República dos sonhos", "O cometa", "A pátria"). Convém salientar que as traduções das duas coletâneas foram publicadas no Brasil ainda nos anos 90 pela editora Imago na série "Lazuli" que apresentava obras de autores estrangeiros, como Sanatório (1994) e Lojas de canela (1996) de Schulz, vertidas para o português por Henryk Siewierski. Como observa o tradutor, "revistas agora para esta nova edição da Cosac Naify, as primeiras versões podiam ser aperfeiçoadas. Foi possível detectar e corrigir alguns erros, encontrar soluções melhores, mas também confirmar que as primeiras versões ainda resistem ao poder de Cronos" (SIEWIERSKI, 2012a, p. 390).

Uma diferença essencial entre as edições da Imago e o volume em foco deve-se à inclusão de um aparelho paratextual bastante desenvolvido: Ficção Completa abre-se com um pequeno artigo do prêmio Nobel polonês, Czesław Miłosz (publicado originalmente em 2 de janeiro de 1989 em "The New Republic"), e encerra-se com trechos do Diário de Witold Gombrowicz e sugestões de leitura sobre a vida e a obra de Schulz. ${ }^{10}$ Um excelente prefácio de Henryk Siewierski contextualiza a interpretação da obra levando em conta (1) o panorama artístico da Polônia e da Europa da época, (2) a biografia do autor, entrelaçada, de um modo inevitável, com o momento histórico, (3) um esboço geral da poética de Schulz, (4) a atividade crítica, ensaística e epistolográfica do autor, (5) a criação plástica, sobretudo na Xiega Batwochwalça, e (6) os problemas específicos da representação na ficção do escritor. O ensaio de Siewierski, apresentando uma síntese muito sucinta das discussões e conquistas da schulzologia nos sessenta anos desde a morte do autor ${ }^{11}$, consegue evitar um tom excessivamente didático, indicando pontos de referência que permitem uma compreensão mais completa da obra traduzida. A história da Polônia e da literatura polonesa constitui, para um leitor brasileiro, uma terra incógnita em um grau ainda maior do que a história do Brasil e da sua

o momento da redação da primeira versão deste texto, em 2013, a editora reduziu o preço do volume e neste momento - no final de 2015 - Fiçãa completa pode ser adquirida no site da editora por $\mathrm{R} \$ 52,90$.)

10 São mencionadas, entre outros, as traduções inglesa e francesa do importante estudo Regiony wielkiej hereşji, de Jerzy Ficowski, catálogos norte-americano e francês de desenhos de Schulz, edições francesa, espanhola e norte-americana de ensaios e da correspondência, comentários de escritores (Roth, Updike, Singer, Coetzee), referências intertextuais (Grossman, Foer, Vila-Matas, Ozick) e adaptações cinematográficas.

11 O ensaio foi escrito originalmente para a edição de Lojas de canela (SCHULZ, 1996, pp. 142-173), não se referindo, portanto, aos estudos mais recentes sobre a obra de Schulz. 
literatura para o leitor polonês. Residente no Brasil, Henryk Siewierski ${ }^{12}$, autor também de História da literatura polonesa (2000) publicada pela Editora da UnB, tem consciência das dificuldades interpretativas que um leitor brasileiro pode enfrentar na leitura de Schulz, pois este entra em uma rede muito complexa de relações com a tradição literária da Polônia e da Europa (cf. SPEINA, 1974), instaurando, ao mesmo tempo, um idioleto muito próprio e inovador, que o tradutor polonês formado em Estudos Poloneses - tem como objetivo manter em sua tradução para o português do Brasil. Na frase que encerra o posfácio, o tradutor afirma que é sua "[a] expectativa que o original esteja presente nessa leitura e, mesmo invisível, acompanhe os leitores de modo que possam não só visitar, mas também habitar o seu mundo" (SIEWIERSKI, 2012a, p. 390).

O papel muito peculiar que Siewierski tem que assumir enquanto tradutor de sua língua materna para uma língua não materna é explicado no prefácio à edição anterior (da Imago) de Sanatório:

Seria talvez mais natural se Schulz tivesse aqui um tradutor cuja língua materna fosse o português. Mas a tradução também pode ser uma leitura em outra língua, leitura com os outros e para os outros. Sinto-me privilegiado por poder fazer esta leitura no Brasil, numa língua que não era minha, mas que se fez minha, tornando irresistível a tentação de nela verter algumas das mais belas páginas da literatura polonesa. (SIEWIERSKI, 1994, p. 13)

Para Siewierski, Schulz tem que ser colocado a uma certa distância, ficando em um campo que permita um olhar ao mesmo tempo próximo, necessário no processo da tradução que procura transmitir a especificidade do original ${ }^{13}$, e dis-

12 Siewierski foi responsável também pela publicação da antologia Quatropoetas poloneses (1994), que inclui traduções de Czesław Miłosz, Tadeusz Różewicz, Wisława Szymborska i Zbigniew Herbert, bem como Adam Mickiewicz: um poeta peregrino (1998). É autor de alguns dos raros livros sobre a cultura e literatura brasileira lançados na Polônia, como Jak dostałem Brasylię w pręencie (1998) e Raj nie do utracenia: amazońskie silva rerum (2006). Coordenou também a tradução coletiva do volume 33 wiersze brasyllijskie (2011), com obras de Carlos Drummond de Andrade, João Cabral de Melo Neto e Mario Quintana vertidas para o polonês. (Cf. a bibliografia completa de Siewierski no site: www.dicionariodetradutores.ufsc.br/pt/HenrykSiewierski.htm. Consulta realizada em 20 de dezembro de 2015).

13 É significativo, neste contexto, um comentário de Siewierski publicado no volume Bruno Schul: Wiosna. 12 præẹkładów: "descobri que a tradução para 'uma outra' língua tem também suas vantagens, porque, apesar de requerer mais tempo e inúmeras consultas das fontes da língua escrita e coloquial, permite uma maior liberdade, e uma menor dependência da tradição literária local que impõe suas exigências. Em nome da fidelidade à tradução, este tradutor pode ultrapassar as fronteiras que, para um tradutor para a sua língua materna, seriam provavelmente inultrapassáveis, explorando novos tons e registros, e convencendo, de uma certa forma, a língua [de chegada] a uma ampliação para que ela receba uma obra que, sem essa 
tanciado, que simule a posição do leitor, para quem o valor e o contexto da obra de Schulz não são óbvios. Esta alteração da perspectiva afetivo-cognitiva, próxima à auto-alienação, é um processo dialético, que, como afirma Teresa Walas:

significa (...) o desenvolvimento (...) em si mesmo de uma perspectiva gêmea, que do ponto de vista hermenêutico é uma inversão daquela [da perspectiva "do olhar estranho"]: enquanto o olhar externo, o olhar de um forasteiro, procura uma relativa redução da distância, o olhar do guia impõe essa distância a si mesmo, buscando uma posição diferente da costumeira, o que resulta também, e certamente o faz, em uma alteração da forma do próprio objeto. (WALAS, 2011, p. 215)

Ainda que a pesquisadora assuma uma perspectiva mais abrangente e que se refira aos desafios enfrentados por pessoas que buscam introduzir sua literatura nacional no exterior e que na cultura de chegada desempenham papel de "guias" ou "orientadores", suas observações podem ser pertinentes do ponto de vista da presente análise.

A atividade do tradutor de uma língua materna para uma não materna, que pretende reduzir a distância que separa o receptor da tradução do texto de partida, tem como consequência a necessidade de sair de sua perspectiva original. A resultante "alteração da forma do próprio objeto" faz parte do processo de refração ( $c f$. LEFEVERE, 1982), em que um papel importante cabe também aos contextos e às explicações fornecidas pelo tradutor-como-guia, que objetiva reduzir as deformações causadas pela inserção do autor traduzido no sistema da cultura de chegada. Uma análise dos primeiros momentos da recepção da tradução brasileira de Ficção Completa de Bruno Schulz permite evidenciar a dinâmica desse processo como um gradativo entrelaçamento da obra com os contextos já circulantes no Brasil.

\section{Schulz x Kafka}

Resumindo os textos dedicados a Bruno Schulz que foram publicados na revista "NaGłos" lançada em 1992 - com comentários de Singer, Roth, Hrabal e Updike, entre outros -, Agnieszka Fulińska afirma:

ampliação, não poderia ter sido criada. Força mais a língua para adaptar-se à obra do que a obra a uma nova língua. Obviamente há certos limites que só podem ser ultrapassados após uma negociação prévia, e outros que não podem ser ultrapassados." (SIEWIERSKI, 2008, p. 298-299). 
A leitura de todos estes comentários permite, primeiro, uma conclusão básica de que Schulz é um fenômeno único no quadro da literatura mundial contemporânea, e, segundo, uma reflexão de que grandes escritores renomados falam de outro grande escritor somente através da comparação com outros grandes escritores. (FULIŃSKA, 1992)

$\mathrm{O}$ autor que com mais frequência constitui um ponto de referência para a interpretação da ficção de Schulz é, sem dúvida, Franz Kafka. Paralelos entre os dois escritores foram feitos várias vezes na Polônia e no exterior - como prova, entre outros, o manual da literatura polonesa de Czesław Miłosz (2012: 493), publicado em inglês - e com base em dois contextos. O primeiro refere-se à atribuição - equivocada - da autoria da tradução de O processo a Schulz - uma suposição já desmentida por muitos especialistas na obra do autor ( $c f$. FICOWSKI, 1967, p. 168-169; BOLECKI, JARZĘBSKI, ROSIEK, 2003, p. 169; MIKLASZEWSKI, 2009 , p. 118) -, enquanto o outro diz respeito a uma aparente semelhança entre a transformação do pai do narrador de Sanatório sob o signo da clepsidra em barata, com a de Gregor Samsa no conto $A$ metamorfose. A coincidência revela-se, porém, apenas superficial, dado que o motivo da transfiguração tem, nos dois autores, um significado totalmente diferente. Um dos primeiros pesquisadores a notar isso foi Jerzy Ficowski (1967, p. 145-146) ${ }^{14}$, o que influenciou as análises posteriores, nas quais os críticos procuram apresentar Schulz num contexto histórico-literário mais amplo, tanto polonês (SPEINA, 1974, p. 68-69), como mundial (BROWN, 1990, p. 224-225).

Apesar de numerosas divergências, que não escapam à atenção de um leitor perspicaz e constituem uma glosa já obrigatória nos estudos sobre a obra de Schulz e de Kafka ( $c$. BOLECKI, JARZĘBSKI, ROSIEK, 2003, p. 170; JARZĘBSKI, 2005, p. 20-21), as referências ao perfil do autor de O processo, enquanto figura internacionalmente reconhecível, acompanharam a recepção de Schulz no exte-

14 "Apenas um conhecimento muito superficial da obra de Schulz pode justificar a hipótese de um parentesco próximo com Kafka. De fato, são dois mundos completamente diferentes, motivos criativos extremamente diversos, filosofias distantes. Schulz tinha muito apreço por Kafka, mas - apesar de suspeitas infundadas - nunca se considerou seu seguidor, nem sequer alguém que compartilhasse seu sonho. Schulz é construtor de uma realidade-asilo que constitui uma 'exacerbação do sabor do mundo'; Kafka é morador e glosador de um mundo de terror, um eremita ascético à espera de um milagre de irrealizável justiça. Schulz - um metafísico, vestido de toda a riqueza de matizes e cores; Kafka - um místico vestindo um cilício de renúncias mundanas. Schulz - criador e imperador de um Mito compensatório; Kafka - explorador sisifista do Absoluto. Schulz - criador pródigo de Olimpos comuns; Kafka - notário de um Abismo avassalador" (FICOWSKI, 1967, p. 145-146). Cf. também o verbete "Kafka" em Stownik schulzowski (BOLECKI, JARZĘBSKI, ROSIEK, 2003, p. 170). 
rior, de forma persistente. Já em 1961, nos primeiros momentos da "viagem ao mundo" do autor de Lojas de canela, Witold Gombrowicz chamou atenção para a ambiguidade da relação que seria sublinhada pelos leitores estrangeiros de Schulz, servindo-se de contextos literários já conhecidos:

O que será? Um fracasso ou um sucesso mundial? Seu parentesco com Kafka tanto pode abrir como fechar-lhe o caminho. Se disserem que é mais um primo, está perdido. Mas se enxergarem o brilho peculiar, a luz própria que emite feito um inseto fosforescente, aí será capaz de entrar suavemente no imaginário, já trabalhado por Kafka e sua estirpe... e então, a êxtase dos gourmets irá jogá-lo para cima. E se a poetização dessa prosa não cansar demais, vai deslumbrar... (GOMBROWICZ, apud SCHULZ, 2012a, p. 391-392).

A recepção de Schulz realiza-se, portanto, no que se pode considerar uma "sombra de Kafka", já que a analogia entre os dois escritores poderia resultar no apagamento da singularidade da ficção do autor polonês. Diante desse risco, a forma da edição brasileira de 2012 parece resultar de uma série de decisões intencional e conscientemente orientadas para o controle da recepção da obra. O artigo de Miłosz, que desempenha a função de prefácio, desde o inicio chama atenção do leitor para a especificidade da linguagem de Schulz enquanto um desafio para o tradutor, e sublinha uma das particularidades mais importantes e mais evidentes do idioleto do autor, que permite uma distinção entre ele e a linguagem do autor de $O$ processo:

Schulz foi traduzido para diversas línguas e, paradoxalmente, parece que seus admiradores mais ferrenhos estão na Alemanha Ocidental. Todavia, não é fácil fazer de Bruno Schulz um escritor internacional. Ele nasceu na Polônia, morreu na Polônia, e o que mais o caracteriza como escritor é a intimidade que demonstra com a língua polonesa. A exuberância, a opulência de sua prosa barroca o distingue do ascético Kafka, e o leva à beira da intraduzibilidade. (MILOSZ, apud SCHULZ, 2012a, p. 9)

Nesta pequena passagem, Miłosz não apenas realça uma distinção ente Schulz e Kafka, mas também sinaliza a singularidade do autor polonês, criador de uma ficção "barroca", inextricavelmente ligada à língua polonesa, que para o leitor brasileiro é um idioma bastante exótico. O volume é encerrado com trechos do diário de Gombrowicz, inclusive a passagem anteriormente citada, que trata dos perigos da identificação de Schulz com o autor de $O$ castelo. 
Apesar da seleção de textos adicionais que procuram impedir analogias entre Schulz e Kafka já na etapa da leitura do volume, as referências kafkianas constituem um lugar comum nos comentários sobre o lançamento de Ficção Completa no Brasil. Neste trabalho, serão mencionados apenas os mais importantes jornais e revistas nacionais, como "O Estado de S. Paulo", "Veja", "Folha de S. Paulo", "O Globo" e "Gazeta do Povo". Convém notar, aliás, que a própria enumeração dos títulos já sinaliza que a edição da Cosac Naify conseguiu uma grande projeção midiática, sendo notada nos mais influentes órgãos da imprensa brasileira.

Em um artigo da revista "Veja" que saiu quase simultaneamente com o lançamento do volume, Jerônimo Teixeira (2012, p. 134) afirma que "Schulz não é desses epígonos kafkianos que grassavam como erva daninha no século passado: seu universo é ao mesmo tempo menos opressivo e mais fluído do que o do autor de O Processo". Refere-se também a um ensaio sobre Schulz escrito por John Maxwell Coetzee, publicado no Brasil apenas um ano antes, em 2011, pela Companhia das Letras, no volume Mecanismos internos. Poucos dias depois do artigo de Teixeira, o suplemento cultural de "O Estado de S. Paulo" divulga a primeira entrevista com o tradutor ${ }^{15}$ (SIEWIERSKI, 2012b). Na introdução lê-se que "Schulz consegue vencer, na visão de Siewierski, a comparação com Kafka, autor de quem se distancia pela exuberante prosa poética, que contrasta com o estilo menos ousado do ficcionista checo" (SIEWIERSKI, 2012b). Observe-se o comentário do tradutor a respeito da base da analogia kafkiana na recepção de Schulz:

Essas comparações resultam mais da vontade de situar Bruno Schulz num determinado contexto histórico e geográfico do que de uma análise da sua ficção. Porque apesar de certas convergências temáticas, são universos e estilos artísticos bem diferentes. A exuberância poética da ficção de Schulz e seu riquíssimo imaginário divergem do estilo protocolar da prosa kafkiana. Se procurarmos as convergências, elas podem ser encontradas sim, mas no plano que aproxima os escritores cujas obras têm caráter universal, pela intensidade com que enfrentam o mistério da vida humana e sua inserção no drama da história. (SIEWIERSKI, 2012b)

O tradutor faz referência também a um famoso posfácio para a tradução de $O$ processo, considerando-o um autocomentário de Schulz, de acordo com o

15 Ubiratan Brasil apresenta Siewierski não apenas como tradutor, mas sobretudo - referindo-se às instituições acadêmicas nacionais e estrangeiras que ele representa - como professor da Universidade de Brasília, mestre em filologia polonesa e doutor pela "Universidade de Cracóvia" (isto é, a Universidade Jaguelônica, dado que a cidade de Cracóvia abriga várias instituições do ensino superior). 
qual, um espaço de convergência entre os dois autores seria o caráter autônomo do seu ambíguo mundo ficcional, resistente às tentativas de uma interpretação totalizante. A referência ao posfácio enquanto um contexto desconhecido ao leitor brasileiro torna a entrevista uma importante fonte de informação suplementar e sinaliza a heterogeneidade de contextos fora do alcance da crítica brasileira. Reconhecendo isso, Ubiratan Brasil pergunta sobre aspectos da obra de Schulz que não foram suficientemente enfatizados. Na resposta, o tradutor alega que a ficção de Schulz é objeto de várias pesquisas na Polônia e no exterior, e cita On the Margins of Reality, um estudo de Krzysztof Stala (publicado em inglês e, por isso, mais acessível para o leitor brasileiro) e complementa: "seria difícil apontar um aspecto da sua prosa [de Schulz] que até agora não tivesse despertado o interesse da crítica" (SIEWIERSKI, 201b). Menciona também o Festival Bruno Schulz em Drohobych, a obra ensaística e a correspondência do autor, bem como a necessidade de aprofundamento dos estudos sobre uma possível relação entre a obra de Schulz e o realismo mágico.

Indagado sobre as eventuais "armadilhas", "perigos" e "perdas", aos quais a ficção do autor é sujeita na tradução para a língua portuguesa - note-se, aliás, que é uma pergunta já baseada numa convicção do valor do original! - Siewierski responde:

Mais do que as armadilhas semânticas que aparecem, porque elas sempre aparecem na tradução literária devido às diferenças culturais e linguísticas, neste caso específico foi preciso ficar especialmente atento ao ritmo. Os períodos sintáticos longos compostos de orações subordinadas, ramificadas, emaranhadas mantêm-se unidos não só pelos recursos de sintaxe, mas também pelo ritmo, pela musicalidade, e perdê-lo seria perder a alma dessa prosa. Outro perigo pode vir da ousadia e da originalidade das construções metafóricas. Elas podem parecer muito estranhas para o leitor da tradução, parecer até um tropeço do tradutor e, ele, pode sucumbir à tentação de domesticar o que é estranho. Mas a graça da tradução não seria justamente levar o leitor a outras regiões do imaginário, mesmo as que cheirassem heresia, fazer com que ele esteja surpreendido assim como é surpreendido o leitor do original? Porém, quando a questão não é surpreender, mas também encantar, como o faz o original, não há como recorrer aos métodos ou roteiros preestabelecidos, tem que entrar em jogo a intuição e aquilo que é chamado a arte de tradução. Os perigos não faltam, por isso também a dívida que o tradutor tem com os revisores, os verdadeiros parceiros na tradução. (SIEWIERSKI, 2012b). 
Siewierski problematiza, de forma aberta, a estratégia da tradução que evita domesticação e procura permitir um encontro do leitor com o novo, o estranho e o distante das dicções poéticas já conhecidas - que procura, enfim, como diz Schleiermacher (2007), levar o leitor até o autor. A tradução da linguagem inovadora de Schulz visa, portanto, a introdução de padrões sintáticos e metafóricos que não pertencem ao repertório formal da literatura brasileira.

No suplemento cultural da "Folha de S. Paulo" de 2 de junho de 2012 sai uma pequena resenha intitulada "Fição Completa apresenta universo de mistérios e utopias de Bruno Schulz", de autoria de Manuel da Costa Pinto. Neste pequeno texto se sublinha a origem judaica do autor e o caráter "messiânico" da sua ficção, realçando a distinção entre o estilo "voluptuoso" de Schulz e a linguagem fria, "inóspita" e "protocolar" de Kafka, mencionando também as diferenças na construção da figura do pai na obra dos dois autores. ${ }^{16}$ Costa Pinto considera o volume "ótimo". Duas semanas mais tarde, no blog "Todoprosa", do site da revista "Veja", é publicada uma resenha dedicada sobretudo à "sombra de Franz Kafka" que acompanha a recepção da obra de Schulz (RODRIGUES, 2012). O autor evidencia uma boa orientação nas vozes mais importantes da crítica no que diz respeito à relação entre os dois escritores: resume uma famosa conversa de Philip Roth com Isaac Bashevis Singer ${ }^{17}$, na qual este alega a superioridade do autor de Lojas de canela sobre o escritor de Praga ${ }^{18}$, mas procura entrar em polêmica com ele, evocando também um outro texto pertinente, isto é, o ensaio de J.M. Coetzee sobre Schulz. O artigo de Rodrigues é sintomático para os primeiros momentos da recepção de Fiç̧ão Completa, revelando a rapidez com que se realizou a inserção

16 O pai do narrador é o único personagem mencionado na primeira fase da recepção de Ficção completa de Schulz no Brasil. Não há nenhuma evocação a outros personagens, como Adela, uma criada sensual e ambígua, muito comentada pela crítica polonesa, mas que parece não despertar interesse na crítica brasileira. Convém lembrar, porém, que a figura de uma criada responsável pela iniciação sexual de jovens rapazes faz parte do imaginário cultural no Brasil, com representações literárias importantes, por exemplo em Amar: verbo intransitivo, de Mário de Andrade (1927). Talvez Adela constitua, portanto, um elemento mais "transparente" na leitura da obra de Schulz feita no Brasil. (Agradeço a Zofia Ziemann, da Univerisdade Jaguelônica, por ter chamado minha atenção a este aspecto da recepção de Schulz.)

17 A entrevista constitui um dos contextos mais evocados na recepção de Schulz no Brasil, dado que o volume Shop Talk. A Writer and His Colleagues and Their Work (2001), que inclui a transcrição da conversa de 1976, foi publicado no Brasil há relativamente pouco tempo, em 2008, como Entre nós. Um escritor e seus colegas falam de trabalho, pela Companhia das Letras.

18 A opinião de Singer é o eixo de um artigo publicado entre maio e junho de 2012 no jornal "Opção" (BELÉM, 2012). Já que o autor do artigo usa a publicação da Cosac Naify como pretexto para um resumo e uma citação extensa da entrevista de Roth, não fazendo menção à nova edição da ficção de Schulz, ele não será aqui discutido. 
do volume em uma rede mais abrangente de referências, por meio da indicação de textos disponíveis para o leitor da tradução ${ }^{19}$. A recepção da edição brasileira da Fiç̧ão Completa de Schulz começa a depender de outras instâncias reguladoras - autoridades reconhecidas no campo da literatura - e a relação entre ele e Kafka passa a ser gradativamente discutida e problematizada. A resenha de Marcelo Paiva de Souza, que sai em meados de junho de 2012 no suplemento cultural de "Gazeta do Povo" (SOUSA, 2012), prova que é possível falar de Schulz sem referências constantes a Franz Kafka, reportando-se a um contexto histórico mais amplo e prestando a devida atenção à particularidade da linguagem do autor de Lojas de canela. ${ }^{20}$

No final de junho daquele ano o jornal "O Globo" considera o lançamento da tradução da Ficção Completa de Schulz merecedor da primeira página do suplemento "Prosa \& Verso" (FREITAS, 2012, p. 1). O artigo de Élida Mara Alves Dantas e Leonardo Francisco Soares (DANTAS, SOARES, 2012, p. 2), impresso na página seguinte, constitui mais um passo no caminho à ativação de contextos interpretativos e referências intertextuais através da evocação dos nomes de Danilo Kiš, cuja obra está presente no Brasil desde meados dos anos 80, e de David Grossman, autor do romance Ver: amor (original See Under: Love, 1986), cuja tradução aparece no Brasil em 2007 pela Companhia das Letras. Na mesma página acha-se uma entrevista com Henryk Siewierski, na qual o tradutor esclarece, entre outros, a relação entre a obra de Schulz e o seu contexto histórico, bem como as ligações entre a obra plástica e literária do autor. Guilherme Freitas, responsável pela entrevista, dedica uma das perguntas à questão das semelhanças e diferenças entre três escritores poloneses: Bruno Schulz, Witold Gombrowicz e Stanisław Ignacy Witkiewicz. Em sua resposta, Siewierski sublinha o caráter criador e inovador das buscas artísticas dos "três mosqueteiros" da prosa polonesa da época, que desenvolveram uma crítica em relação ao futuro. Quando o entrevistador se refere a um suposto "parentesco" de Schulz com Kafka e a um possível perigo que, conforme a opinião de Gombrowicz, pode decorrer dele para a recepção do autor de Sanatório sob o signo da clepsidra, Siewierski (2012c, p. 2) explica:

19 Como se disse, uma lista detalhada das fontes e referências disponíveis ao leitor brasileiro é incluída no final do volume de Fição completa.

20 Vale lembrar que o autor desta resenha, Marcelo Paiva de Souza, é um leitor com qualificações particularmente elevadas. Ex-orientando de Henryk Siewierski e doutor em Estudos Literários pela Faculdade de Letras Polonesas da Universidade Jaguelônica, foi também responsável pela revisão das traduções editadas em Sanatório, de 1994, e coordenador do curso de Polonês na Universidade Federal do Paraná. Tem, portanto, acesso ao texto original e a vários comentários críticos em polonês. 
A associação de Schulz com Kafka geralmente resulta de uma leitura superficial das suas obras ou da supervalorização de certas semelhanças biográficas e geográficas. (...) Na época stalinista, em que Kafka era um dos mais suspeitos e desaconselhados autores do século XX, semelhanças desse tipo contribuíram para a marginalização da obra de Schulz na Polônia e no bloco soviético. Mas há mais diferenças do que semelhanças, a começar pelo estilo - tão exuberante e poético em Schulz, e tão protocolar e seco em Kafka. Enquanto Kafka representava a alienação total e o desespero metafísico do indivíduo, Schulz procurava restituir-lhe a cidadania no mundo e reconstruir uma ordem universal. Há também semelhanças, mas nos níveis mais profundos, das suas obras, que têm a ver, por exemplo, com o modo de representação da situação existencial de seus protagonistas através de acontecimentos fantásticos e dom imaginário simbólico.

Siewierski projeta o problema do cotejo dos dois autores para o campo da recepção, mostrando, desse modo, como uma aproximação entre Schulz e Kafka resultou na proibição da circulação da ficção do escritor polonês na época da dominação soviética.

Curiosamente, é a questão da coragem perante os governos totalitários que constitui o núcleo da resenha de Kelvin Falcão Klein (2012), que sai em outubro daquele ano no jornal literário "Rascunho". Klein compara Bruno Schulz com alguns escritores seus contemporâneos - Elias Canetti, Alfred Döblin e Hermann Broch - como um exemplo de autor que luta pela "sustentação de uma individualidade", contra os mecanismos desumanizantes do poder: "Ler Schulz e sua Fiç̧ão Completa, portanto, é entrar em contato com um ato de coragem e de exaltação da imaginação que, atravessando o tempo, nos alcança e atinge" (KLEIN, 2012, p. 23). O artigo em "Rascunho" resulta de uma leitura atenta da obra do polonês à luz de contextos que permitem uma interpretação mais completa e a inserção do autor no sistema literário brasileiro por meio de referências preexistentes. Uma ativação gradativa de comentários e evocações importantes para o discurso de recepção nos momentos imediatamente posteriores ao lançamento do volume leva, com uma velocidade surpreendente, a uma situação que se pode considerar "um desejo de uma schulzologia brasileira", uma vez que Klein critica a edição de Cosac Naify por não ter incluído a obra ensaística e a correspondência, mencionadas por Gombrowicz, Kiš, Coetzee e Roth. Um leitor fascinado com Fiç̧ão Completa não consegue ultrapassar a fronteira constituída pela necessidade da tradução. Só se pode esperar que o comentário de Klein anuncie um interesse futuro pela totalidade da obra de Schulz. Para Klein, Kafka já não constitui um quadro textual indispensável para a contextualização da obra do autor de Lojas 
de canela - o nome Kafka é mencionado apenas de passagem, quando se fala do conhecimento do idioma alemão, que no caso de Schulz, lhe permitiu acesso aos escritos de Freud. Klein analisa a linguagem de Schulz - quer dizer, a linguagem de Schulz moldada em português por Siewierski - do ponto de vista dos contextos freudianos ativados ao nível do léxico. Cita também o trecho final da tradução de Tratado dos manequins para "[dar] a medida do fluxo poético de Schulz" (KLEIN, 2012, p. 23), indicando, desse modo, a singularidade do idioleto do autor que, aparentemente, foi preservado na tradução orientada para a sustentação da particularidade da linguagem do texto original.

\section{Seis meses de Schulz}

As considerações finais, baseadas na presente análise dos primeiros momentos da recepção da Fiç̧ão Completa de Bruno Schulz no sistema literário brasileiro podem ser resumidas em duas observações.

Primeiro, a introdução de sua obra realizou-se por meio de uma combinação de fatores: a edição da Cosac Naify foi lançada no sistema literário de chegada em um contexto crítico preexistente (traduções da entrevista de Roth e Singer, e o ensaio de Coetzee) e intertextos literários também já existentes (Kafka, depois também Kiš e Grossman). Ao mesmo tempo, verifica-se a ausência de referências explícitas à recepção das edições anteriores de Schulz no Brasil, o que sugere o caráter descontínuo da recepção brasileira do autor e indica que depois do lançamento da Cosac Naify a recepção da obra de Schulz se realiza, de uma certa forma, de novo. ${ }^{21}$ Observa-se também uma falta de tentativas de comparação de Schulz com autores nacionais, o que pode apontar para o caráter fortemente inovador da publicação na cultura de chegada, que coloca a literatura traduzida no centro ativo do seu sistema. O caráter experimental da ficção schulziana foi também muito reconhecido pela crítica.

Segundo, devido à falta de outras referências, um quadro receptivo para a ficção do autor foi constituído a partir da obra de Franz Kafka. A relação entre os dois escritores é discutida à luz dos comentários evocados pela crítica. Nesta situação, o tradutor desempenha o papel de expert e de orientador, e as suas in-

21 A descontinuidade da recepção de Schulz no Brasil significa aqui uma ausência, na crítica posterior à edição de 2012, de qualquer referência ao bom acolhimento das primeiras traduções da obra do autor no Brasil nos anos 90, publicadas pela Imago, sem as quais, no entanto, o projeto da Cosac Naify provavelmente não se teria concretizado. 
tervenções exercem uma função reguladora no processo da recepção da obra na cultura-alvo. A sua tarefa enquanto um agente de refração consiste na ordenação de uma rede de referências intra-sistêmicas no processo da sua constituição, o que exige que o tradutor assuma o ponto de vista do receptor, já que o último, muitas vezes, é privado de conhecimentos e competências (linguísticas, mas não só) necessárias para a interpretação dos novos elementos. A estratégia tradutológica, que procura ampliar o repertório das formas de expressão artística na literatura brasileira por meio de uma reprodução fiel da singularidade da ficção do autor, tem por objetivo introduzir Schulz como uma força transformadora atual e ativa dentro do sistema, ou seja, um cidadão da literatura brasileira.

\section{Referências}

BELÉM, Euler de França. Bashevis Singer diz que Bruno Schulzé maior do que Kafka. In: Opscão, ed. 1925, 27 de maio - 2 de junho de 2012. Página eletrônica: http://www.jornalopcao. com.br/colunas/imprensa/bashevis-singer-diz-que-bruno-schulz-e-maior-do-que-kafka . Consulta realizada em 20 de dezembro de 2015.

BOLECKI, Włodzimierz; JARZĘBSKI, Jerzy; ROSIEK Stanisław (eds.). Stownik schulzowski. Gdańsk: Ssłowo/obraz terytoria, 2003.

BRASIL, Ubiratan. Nossas escolhas de 2012. In: O Estado de S. Paulo, "Caderno 2", 21 de dezembro de 2012. p. D6.

BROWN, Russell E. Bruno Schulz and World Literature. In: The Slavic and East European Journal, Vol. 34, No. 2, 1990. pp. 224-246.

DANTAS, Élida Mara Alves; SOARES, Leonardo Francisco. Uma obra interrompida pela guerra. In: O Globo, "Prosa \& verso", 23 de junho de 2012. p. 2.

EVEN-ZOHAR, Itamar. The Position of Translated Literature within the Literary Polysystem. In: Poetics Today, Vol. 11, No. 1, 1990. pp. 45-51.

FICOWSKI, Jerzy. Regiony wielkiej bereyji: szkice o życiu i twórczości Brunona Schulza. Kraków: Wydawnictwo Literackie, 1967.

FIUT, Aleksander. Schulz jako bohater literacki. In: KITOWSKA-LYSIAK, Małgorzata; PANAS, Władysław (eds.). W ułamkach zwierciadła...: Bruno Schulz w 110 rocznicę urodzin i 60 rocznicę śmierci. Lublin: Towarzystwo Naukowe KUL, 2003.

FREITAS, Guilherme. A sombra de Schul:. In: O Globo, "Prosa \& verso", 23 de junho de 2012. p. 1.

FULIŃSKA, Agnieszka. Bóg stworzył Kafke i Schulza. In: Dekada Literacka, t. 24, nr 1, 1992. Página eletrônica: http://dekadaliteracka.pl/index.php?id=2669. Consulta realizada em 1 de junho de 2013. 
JARZECBSKI, Jerzy. W stęp. In: SCHULZ, Bruno. Opowiadania. Wybór esejów i listów. WrocławWarszawa-Kraków: Zakład Narodowy im. Ossolińskich, 1998.

Prowincja centrum: przypisy do Schulza. Kraków: Wydawnictwo Literackie, 2005.

KLEIN, Kevin Falcão. Um mundo que troca de pele. In: Rascunho, ed. 150, 2012. p. 23.

LEFEVERE, Andre. Mother Courage's Cucumbers: Text, System and Refraction in a Theory of Literature”. In: Modern Language Studies, Vol. 12, No. 4, 1982. pp. 3-20.

MIKLASZEWSKI, Krzysztof. Zatracenie sie w Schulzu: historia pewnej fascynacji. Warszawa: PIW, 2009.

MILTON, John, BANDIA, Paul (eds.). Agents of Translation. Amsterdam-Philadelphia: John Benjamins, 2009.

MIŁOSZ Czesław. Historia literatury polskiej. Przeł. M. Tarnowska. Kraków: Znak, 2010.

PINTO, Manuel da Costa. Ficção Completa apresenta universo de mistérios e utopias de Bruno Schulz. In: Folha de S. Paulo, "Ilustrada", 2 de junho de 2012. Página eletrônica: http:// www1.folha.uol.com.br/fsp/ilustrada/46329-quotficcao-completaquot-apresenta-universo-de-misterios-e-utopias-de-bruno-schulz.html . Consulta realizada em 20 de dezembro de 2015.

RODRIGUES, Sérgio. Bruno Schulz - Ficção Completa: gênio de beber. Publicado em 13 de junho de 2012. Página eletrônica: http://veja.abril.com.br/blog/todoprosa/resenha/ bruno-schulz-ficcao-completa-genio-de-beber . Consulta realizada em 20 de dezembro de 2015.

SCHLEIERMACHER, Friedrich. Sobre os diferentes métodos de traduæir. Tradução de Celso Braida. In: Princípios, v. 14, n. 21, 2007. pp. 233-265.

SCHULZ, Bruno. Sanatório. Tradução de Henryk Siewierski. Rio de Janeiro: Imago, 1994.

. Lojas de canela. Tradução de Henryk Siewierski. Rio de Janeiro: Imago, 1996.

. Opowiadania. Wybór esejów i listów. Wrocław-Warszawa-Kraków: Zakład Narodowy im. Ossolińskich, 1998.

. Fição Completa. Tradução de Henryk Siewierski. São Paulo: Cosac Naify, 2012a.

As lojas de canela. Tradução de Anibal Fernandes. Lisboa: Sistema Solar, 2012b.

SIEWIERSKI, Henryk. Bruno Schulzw Brazylii. In: MENIOK, Wiera (ed.). Bruno Schulz: Wiosna: 12 przekładów. Drohobycz-Lublin: Polonistyczne Centrum Naukowo-Informacyjne im. Igora Menioka Państwowego Uniwersytetu Pedagogicznego im. Iwana Franki - Stowarzyszenie Festiwal Brunona Schulza, 2008. pp. 298-299.

. "Posfácio". Tradução. In: SCHULZ, Bruno. Fiç̧ão Completa. Tradução de Henryk Siewierski. São Paulo: Cosac Naify, 2012a. pp. 369-390.

2012b - Linhas de Força de um Gênio (entrevista com Ubiratan Brasil). In: $O$ Estado de S. Paulo, 18 de maio de 2012. Página eletrônica: http://www.estadao.com.br/ noticias/arteelazer, linhas-de-forca-de-um-genio,874825,0.htm . Consulta realizada em 20 de dezembro de 2015. 
. 2012c - Schulz tratava a literatura como remédio para a crise (entrevista com Guilherme Freitas). In: O Globo, "Prosa \& verso", 23 de junho de 2012. p. 2.

SOUZA, Marcelo Paiva de. O pincel da palavra de Bruno Schulz. In: Gazeta do Povo, "Caderno G”, 16 de junho de 2012. Página eletrônica: http://www.gazetadopovo.com.br/cadernog/ conteudo.phtml?tl=1\&id=1265677\&tit=O-pincel-da-palavra-de-Bruno-Schulz. . Consulta realizada em 20 de dezembro de 2015.

SPEINA, Jerzy. Bankructwo realności: proza Brunona Schulza. Warszawa-Poznań: PWN, 1974.

STALA, Krzysztof. Na marginesach ræẹzymistości: o paradoksach przedstawiania w twórczości Brunona Schulza. Warszawa: Instytut Badań Literackich PAN, 1995.

TEIXEIRA, Jerônimo. Estranheza doméstica. In: Veja, 16 de maio de 2012. p. 134.

WALAS, Teresa. Oko innego/ cudzoziemca jako możliwa perspektywa poznawcza literatury polskiej. In: NYCZ, Ryszard; MIODUNKA, Władysław; KUNZ, Tomasz (eds.). Polonistyka bez. granic, t. 1, ”Wiedza o literaturze i kulturze”. Kraków: Universitas, 2011. pp. 213-221.

WILCZEK, Piotr. Kanon literatury polskiej jako wyz̧wanie dla zagranicznego polonisty. Problem przekładu. In: NYCZ, Ryszard; MIODUNKA, Władysław; KUNZ, Tomasz (eds.). Polonistyka bezgranic, t. 1, "Wiedza o literaturze i kulturze". Kraków: Universitas, 2011. pp. 563-569. 